\title{
An Analysis on the Lack of Humanistic Care in Ideological and Political Education in Universities and its Countermeasures
}

\author{
Binbin $\mathrm{Yu}^{1, \mathrm{a}}$ and Yue Teng, ${ }^{2,}$, * \\ ${ }^{1}$ Beihua University, College of Information Technology and Media, China \\ ${ }^{2}$ Beihua University, College of Economics and Management, China \\ a22342690@qq.com, b124132250@qq.com \\ * please mark the corresponding author with an asterisk
}

Keywords: Colleges and universities; Humanistic education; Ideological and political education; Educational reform.

\begin{abstract}
While carrying out ideological and political education, colleges and universities generally focus only on books, and seldom give humane care to students. This is a drawback to the education of college students. This will cause the lack of humanistic feelings of college students and lead to the low effect of ideological education. In order to carry out ideological education more effectively, we should actively guide students to develop good humanistic feelings. Only when students have established good humanistic feelings can ideological and political education be carried out efficiently. This paper analyzes the phenomena of the lack of humanistic care in common university education and puts forward some suggestions for developing humanistic education.
\end{abstract}

\section{Introduction}

In the teaching of higher education in China, universities often pay more attention to the education and training of basic knowledge and skills, rarely target on the students' ideological and political education, resulting in the lack of ideological and political education. This kind of morbid teaching mode is not only irresponsible to students, but also a distortion of teaching concept.

\section{The Lack of Humanistic Education in Colleges and Universities}

Ignoring the Needs of College Students when Making Teaching Plans. As early as the school is making the teaching plan, it will be made according to the teaching resources of the school, which leads to the problem that part of the teaching plan does not meet the actual requirements of the students themselves. For example, too much emphasis is put on engineering students' skills training, ignoring their humanistic education; whereas for literature students, often too much emphasis is put on the cultivation of literature, thus imperceptibly too much into the humanistic education. Therefore, colleges and universities should consider and respect the students' needs in line with the development of their teaching plan.

Adjusting Political Education to Students in Accordance with their Aptitude. Students in colleges and universities come from different areas. However, the ideological and political teaching materials at the present stage are the same. Teachers should explain the teaching content of the textbook in different depth, with different teaching methods. Teaching style will affect the quality of teaching effect. In addition, ideological and political education in colleges and universities should have different teaching focus according to different knowledge needs of students; thus, efficiently carries out ideological education work.

Paying Attention to Humanistic Emotion Experience. Presently, most of the ideological education in colleges and universities still stay at literal level; that is the traditional "teacher talk" and "student monologue" situation. This method of ideological and political education is not conducive to students. They can hardly full-understand the real idea of ideological and political education. It is necessary to aware that the ideological and political education is one of the most essential education; it 
is the leading direction of a person's development; it is related to the fate of a country. Therefore, to effectively carry out the ideological and political education, teachers should let the students to actively participate in the teaching process. The most direct and effective way is to give them emotional vibes. If in the teaching process teachers can cause the student emotion sympathetic chord, the teaching effect will certainly be perfect.

\section{Suggestions on the Development of Ideological and Political Education}

Student-oriented Teaching Philosophy should be Implemented. Full consideration of the needs of students themselves should be taken into the course of ideological and political education. Student-oriented teaching philosophy should be implemented in the teaching process of this course. It is of vital importance to understand that teaching staff (not only teachers functions as policy makers in the schools and learning guides of students, rather than main body in the teaching process. Therefore, in the process of ideological and political teaching, teachers should: take full account of the needs of college students as the teaching standard; regard the students themselves as the main body of education, and teachers are a participant and guide in the teaching process; make certain communication and interaction, set an example to students in order to promote the effect of teaching.

Innovate and Change Should be Made in Ideological and Political Education. In the teaching of modern ideological and political education, the teaching methods are still relatively backward, and the teaching results obtained are not very reasonable. With the progress of science and technology, modern means of teaching gradually entered the classroom. Educators should timely learn the new teaching methods. Because modern educational technology brings convenience into the classroom, improve classroom education, improve the teaching level. Firstly, teachers should actively learn modern teaching technology. For senior teachers, school should hold some training class to help them learn advanced information technology. Secondly, teachers should change their teaching methods, combined with new teaching content, so that their classroom language expression is more convincing and expressive. Finally, in the process of teaching, teachers should try to create a harmonious and interesting classroom atmosphere. Students can feel the charm of the teacher, feel the charm of the ideological and political education, thus, to improve the effectiveness of ideological and political education. It should be remembered that the ideological and political education work more on changing people's understanding of the world, and changing people's minds. Therefore, from the perspective of students' own interests, giving them more humanistic care on class will make the classroom teaching more attractive.

The Concept of Humanistic Education and the Means of its Implementation Should be Strengthened. Colleges and universities, on the one hand, imparts knowledge and skills to students; on the other hand, teaches students how to behave appropriately. College Students usually do not have rich life experience and emotional experience. If reasonable teaching methods are taken, it is easily to guide them to the direction they are expected. Hence, when colleges and universities carry out the ideological and political education, the promotion of humanistic concept should be paid more attention to. Teachers lay more emphasis on the role of humanistic concept rather than requiring students to complete the requirements on the syllabus. This means: teachers should have a reasonable grasp on students' present life and their emotions, which is the base to carry out ideological and political education. In addition, even though university life will lead to inadequate communication between teachers and students, teachers should know students' real life. If students encounter difficulties in life, teachers should provide necessary and possible help. This is the humanistic education itself. In terms of teaching methods, teachers should go further on explaining the teaching content, instead of providing some superficial understanding. The teaching activity needs resources. Colleges and universities should provide some teaching resources of ideological and political education, properly input manpower and material resources, let students enjoy their university education in the classroom and feel the charm of humanistic education. 
Knowledge in and out of the Classroom Should be Integrated, Attention Should be Paid on the Infiltration of Humanistic Knowledge. In order to infiltrate the concept of humanistic education and display its characteristics, meanwhile improve the quality of classroom teaching, humanistic education can be carried out not only in the classroom of ideological and political education. Ideological education not only lies in the content written in books, but also originates from life practice. Efficient classroom ideological and political education is one of the source of training students, and life is a bigger classroom. Teachers can infiltrate the content of ideological and political education appropriately when they teach other courses. With the infiltration of bits and pieces in the class, the students' thoughts will change inadvertently. Hence, all the teachers can participate in the ideological and political education. It is never a work for certain individual teachers, but all the teachers in common. Only by fully integrating the teaching resources of schools and infiltrating ideological and political education into every course of the school can the effectiveness of ideological and political education be full played in schools.

An Ideological Teaching Atmosphere and a Harmonious Campus Should be Constructed. Ideological education is closely related to the environment, and the students' living environment will determine their ideological behavior to a certain extent. Therefore, schools should pay attention to the construction of campus atmosphere. For example, in Tsinghua University and other institutions of higher education, because the campus atmosphere of learning, the students will highly focus on academic knowledge. Efficient development of ideological and political education is of the same reason. Colleges and universities can carry out humanistic knowledge contest and some other activities to promote the humanistic education in ideological and political education.

\section{Summary}

In conclusion, education and teaching are closely related to each other. The ideological and political education of colleges and universities and the education of humanistic feelings, as well as the atmosphere of campus education are inseparable. In carrying out ideological education, schools should comprehensively consider various teaching factors so as to enable students to develop in an all-round way.

\section{Acknowledgements}

This work is supported by the Education and Science Planning Project of Jilin Province (Grant GH170091).

\section{References}

[1] L.P Zhai: Journal of Shandong Youth University of Political Science, Vol. 139 (2009) No.3, p.75. (In Chinese)

[2] X.L Dai: Journal of new educational times, (2014) No.5, p.67. (In Chinese)

[3] C. Meng: Journal of Heilongiiang Institute of education, Vol. 34 (2015) No.5, p.98. (In Chinese)

[4] J. Deng: Present situation analysis and countermeasure research of humane care of ideological and political education of poor college students (MS., Southwestern University, China 2010), p.12. (In Chinese)

[5] Y. Li: Research on humanistic care in Ideological and political education in Universities (MS., Nanjing University of Aeronautics \& Astronautics, China 2010), p.26. (In Chinese)

[6] Y.H Yang: Research on humanistic care of Ideological and political education in Colleges and universities in the Internet age (MS., Nanjing University of Posts and Telecommunications, China 2016), p.28. (In Chinese)

[7] M. Wu: study of humanistic care in Ideological and political education in Colleges and universities (MS., Liaoning Normal University, China 2012), p.18. (In Chinese) 
[8] Q.H Yang: Journal of Yangzhou University(Higher Education Study Edition), Vo1.13 (2009) No.1, p.23. (In Chinese)

[9] C.J Wang: Education and Vocation, Vo1.811 (2014) No.27, p.67. (In Chinese)

[10]Z.J Xu: Leading Journal of Ideological \& Theoretical Education, Vo1.224 (2017) No.8, p.152. (In Chinese) 